\title{
Does Subsistence Farming Ameliorate Hunger in Urban Areas? A Quantitative Examination of Urban Areas in South Africa
}

\author{
Coretta M.P. Jonah ${ }^{1, *}$, Rejoice Mabhena ${ }^{2}$ and Julian D. May ${ }^{1}$ \\ ${ }^{1} D S T-N R F$ Centre of Excellence in Food Security, University of the Western Cape, South Africa \\ ${ }^{2}$ Institute for Social Development, University of the Western Cape, South Africa
}

\begin{abstract}
Africa, with its growing urban population, faces the problem of increased demand for food in urban areas and pressure on urban food systems. Lack of employment opportunities, rising levels of urban poverty and food costs further compounds the urban food problem resulting in high levels of urban hunger and consequently food insecurity. Using the General Household Surveys from 2015 to 2017, we examine the association between subsistence farming practices and hunger in urban South Africa. We estimate three models for hunger at the household level; child hunger, adult hunger and hunger in either adult or child. The findings reveal that female-headed households are more likely to engage in subsistence farming. Women, children and the unemployed are at risk of hunger. We find no association between subsistence farming and hunger in urban areas. Measures of economic welfare; incomes, employment and a household member receiving a social grant are significantly associated with the absence of hunger. The results point to the fact that new urban residents as a matter of necessity need the means to earn an income as this is critical in safeguarding them from hunger.
\end{abstract}

Keywords: Hunger, subsistence farming, urban agriculture, food security, urbanisation.

\section{INTRODUCTION}

Amidst high levels of poverty and rising inequality (Bhorat and Naidoo, 2017), the global challenge of food insecurity is one of the main concerns on Africa's development agenda today. Additionally, a high rate of urbanisation has led to the emergence of both an urban poverty and food insecurity challenges. These challenges are concerning in the context of Africa, where they have historically been rural concerns (UN, 2018) and for most parts remain unaddressed.

Despite growing evidence (Faye et al., 2011; Battersby, 2012) on the nature of urban food insecurity and the changing face of Africa's food insecurity problem, response from policymakers has been slow. Many countries on the continent are now struggling with both unaddressed high rates of rural poverty and food insecurity and an increasing urban threat of both poverty and food insecurity.

The United Nations (UN) estimates that by 2030 $55 \%$ of the global population will reside in urban areas (UN, 2018). In 1950 only $30 \%$ of the world population lived in urban areas (UN DESA, 2018). This translates to a rise in the global urban population from 751 million people in 1950 to 4.2 billion in 2018 (UN, 2018). By 2050 , this is expected to increase to $68 \%$ and an estimated $90 \%$ of this expansion in the global urban

*Address correspondence to this author at the DST-NRF Centre of Excellence in Food Security, University of the Western Cape. School of Government Building, Robert Sobukwe Road/Private Bag X17, Bellville (7535), South Africa; Tel: 0027219593856; E-mail: cmpjonah@gmail.com population will be driven by the projected increases in the urban populations of Asia and Africa (UN, 2018).

Africa is one of the fastest urbanising regions in the world. This is partly a result of the fact that the continent remains mostly rural (Seto et al., 2017). For example, North America, one of the most urbanised regions in the world has $82 \%$ of its population residing in urban areas, while in Africa only $43 \%$ are in urban areas (Seto et al., 2017). Although Asia accommodates $54 \%$ of the global urban population, it has a relatively lower rate of urbanisation (UN DESA, 2018). In 1950, Africa had only $11 \%$ of its population residing in urban areas and this changed to $39 \%$ in 2015 and $43 \%$ in 2018 (UN, 2018).

South Africa's urban population growth rate at 2.3\% is outpacing the global urban growth rate of $2.0 \%$ as well as its total national population growth rate but this remains below the African urban growth rate of $4.1 \%$ (Gardner, 2018). Conflictingly, in another research, the rate of urbanisation in South Africa over the past 20 years is described as steady (Arndt, Davies and Thurlow, 2019). Regardless of this contention, $71 \%$ of the country's population is expected to be residing in urban areas in 2030, and this is expected to rise to $80 \%$ in 2050 (Parliamentary Monitoring Group, 2018). According to the National Department of Human Settlements the bulk of this population increase will be in the regions of Ethekwini, Cape Town and Gauteng (National Department of Human Settlements., 2015).

Historically, urban areas with their host of opportunities have played critical roles as hubs for 
economic growth and poverty reduction (UNHABITAT., 2016). However, the current rapid urbanisation of developing countries rather seems to be increasing poverty and has become a threat to food security (Szabo, 2016). This can partly be explained by the context within which rapid urbanization is occurring in these regions. For instance (AfDB., UNDP. and OECD (2016) state that rapid urbanisation in African countries has not been accompanied by the expected structural transformation

In what has been termed the urbanization of poverty' by the South African Cities Network (SACN, 2016:24), the urbanisation experience in Africa has been mostly driven by either conflict or poverty; in comparison to the global North where industrialisation shaped the same process. An outcome of this process of urbanisation is that the poor are getting more concentrated in urban areas and poverty is becoming more urban (Ravallion, Chen and Sangraula, 2007).

Beyond concerns around poverty, rapid urbanisation in developing countries is also shaping the trends in food security and nutrition (IFPRI, 2017). The growing population in urban areas is also anticipated to place increasing pressure on the global food system, worsening the triple burden of malnutrition, undernutrition and overnutrition in this region (IFPRI, 2017). The "urbanisation of poverty" manifests itself in increased reliance by urban dwellers on the informal economy for food and jobs leaving them vulnerable (IFPRI, 2017). Wurwarg (2014) also found that cities in developing countries face chronic hunger, worsened by the rising food prices.

Szabo (2016) argues that urbanisation poses challenges in food availability, access and food stability. Food availability, for instance, is threatened by an increasing urban population that demands more food in 'an environment not traditionally perceived as appropriate for agriculture' (Szabo, 2016:30). Food access, on the other hand, is compromised by the existence of inadequate infrastructure that is worsened by a general lack of financial access to purchase adequate food (Szabo, 2016). More specifically, Ruel and Garrett (2004) find that urban dwellers are likely to buy more than $90 \%$ of their food on the market; subjecting them to the fluctuations of food prices. This places them at an increased risk of hunger. Wurwarg (2014) found that the increasing food prices that kicked in with the global crisis of 2007 and 2008 affected the urban poor more than their rural folks as they are more dependent on the market for food.
The result is that the urban poor with inadequate employment and poor sanitation are at the risk of consuming insufficient and low-quality food (IFPRI, 2017). This overreliance on purchased food in urban areas accompanied by the increasing urbanisation in developing countries is expected to be greater; worsening food insecurity in urban centres (Szabo, 2016). This risk to food insecurity in urban areas is more likely to affect urban dwellers in informal settlements where socioeconomic development is already lower than in rural areas (UNICEF, 2010).

In Sub Saharan Africa, the overreliance on markets for food access worsens the incidences of food insecurity amongst the urban poor. In South Africa, there has been a decline in the number of households that cite agriculture as the primary source of food, but there has been an increase in the number of households engaging in subsistence agriculture to supplement market purchases (Baiphethi and Jacobs, 2009). Rapid urbanisation also poses a paradox- as the increasing population pressure translates to higher demand in food, it places a burden on existing space for food production (Crush, Hovorka and Tevera, 2011).

The rest of the paper is organized as follows; the next section presents a discussion on food security and subsistence agriculture, followed by a presentation of the methods, analysis and discussions. Finally, conclusions, recommendations and study limitation are presented.

\section{FOOD SECURITY, HUNGER AND URBANISA- TION: THE RELEVANCE OF SUBSISTENCE AGRICULTURE}

The Food and Agricultural Organization (FAO) defines food security as, 'a situation that exists when all people, at all times, have physical, social and economic access to sufficient, safe and nutritious food that meets their dietary needs and food preferences for an active and healthy life' (FAO., 2010:8). Hunger, on the other hand, refers to the 'discomfort, illness, weakness or pain' that arises as a result of a 'prolonged involuntary lack of food' (NRC, 2006:48). Hunger remains a challenge mostly affecting developing countries since they are more food insecure (FAO et al., 2018).

More so, hunger within households is integral to food insecurity and remains vital in the fight to end food insecurity. An analysis of the incidences of hunger globally shows that the majority of the world's hungry people are located in developing countries. The 
number of undernourished people has increased from 804 million in 2016 to 821 million in 2017 (FAO et al., 2018).This study analyses the incidence of hunger experienced within households as a component of food security and argues that the attainment of food security can only be achieved with the eradication of hunger.

Households access food through three main channels: markets, subsistence farming or home production and transfers (Baiphethi and Jacobs, 2009). In line with this, there is a commendable number of studies that have focused on urban agriculture/subsistence agriculture and food security (Baiphethi and Jacobs, 2009; Battersby, 2011; Crush and Frayne, 2011; Frayne, McCordic and Shilomboleni, 2014; Tibesigwa and Visser, 2015; Ncube and Ncube, 2016).

In South Africa, urbanisation has arguably created an invisible crisis of food security in urban areas (Crush, Hovorka and Tevera, 2011), justifying enquiry into the relevance of subsistence farming practices in urban areas. Also, urban agriculture has gained more attention due to the increasing rate of urban poverty, hunger and lack of formal employment as well as the potential that urban agriculture has for even the poorest (van Veenhuizen, 2006). In a way, urban agriculture is seen as a logical policy response to hunger and food insecurity at the household level.

The relevance of urban agriculture as a way of achieving food security is not a new concept. For instance, Bryld (2003) argues that urban agriculture has been an important livelihood strategy in urban households for centuries in developing countries and it expanded in these countries mainly as a result of poverty; especially in the period after the implementation of Structural Adjustment Programs (SAP). The SAP were noted to have increased poverty significantly during the early 1990s. Egal, Valstar and Meershoek (2001) argue that urban agriculture by increasing food availability, accessibility and stability contributes to food security.

While food insecurity remains both a rural and urban problem (Tibesigwa and Visser, 2015), the possibilities offered by subsistence agriculture or home production are not homogenous within these two geographic spaces. The effect of these confounding factors like; tenure, access to water and financial markets, gender roles and other factors are different within rural and urban settings.
Furthermore, existing research disagrees on the nature of the linkages that exist between urban agricultural practices and food security. To this effect, authors (Chihambakwe, Mafongoya and Jiri, 2018) point to the lack of concrete statistical work that provides evidence on the impact of subsistence agriculture in urban areas on food security. Researchers (Gallaher et al., 2013; Bellwood-Howard et al., 2015) also found that urban agriculture plays a role in households' food security, while (Crush, Hovorka and Tevera, 2011) caution on the potential overestimation of urban agricultural practices to food security. The association between urban agriculture and food security are so complex that some studies have failed to establish a clear contribution between urban agriculture and food security (Frayne, 2005; Thornton and Nel, 2007). Other results are more promising however as they find that subsistence agriculture contributes more to food security in rural areas than urban settings (Tibesigwa and Visser, 2015).

Despite this lack of a widely accepted causal relationship between subsistence agriculture and food insecurity, there is a consensus that urban agriculture partly addresses consumption in urban areas and reduces expenditure on food (Gallaher et al., 2013; Bellwood-Howard et al., 2015).

Unless fully understood and addressed, the urban food insecurity challenge in Sub Saharan Africa will persist. A starting point to finding a solution is an understanding of the nature and causes of various dimensions of food security in urban settings where little is known (Chihambakwe, Mafongoya and Jiri, 2018). This study focuses on hunger and answers the following questions: What are the urban hunger levels and do male and female-headed household experience varying levels of hunger? The second question is, does subsistence farming or home production ameliorate hunger in urban areas?

\section{METHODS}

\section{Study Design}

The paper conducts a repeated cross-sectional analysis using data from South Africa's General Household Survey (GHS) from the year 2015 to 2017.

\section{Data Source}

The GHS is a nationally representative crosssectional dataset. The survey has been conducted 
every year since 2002. It collects information on the critical characteristics of the country's population at the household level. The specific characteristics include: education, health and social development, housing, household access to services, food security, and agriculture (Stats SA., 2017b).

The GHS is also one of the few surveys in the country that provides data for the assessment of household food security, generally including variables on hunger. Concerning food security domain, the question of hunger has been the most consistent and has been available since the inception of the survey in 2002. While the purpose of the survey is to track progress on key development indicators nationally, the availability of demographic and socioeconomic data on households make the survey the most suitable for the analysis of household food insecurity at the national level.

The survey adopts a stratified two-stage design with probability proportional to size (PPS) sampling of primary sampling units (PSUs) in the first stage and sampling of dwelling units (DUs) with systematic sampling in the second stage (Stats SA., 2017b). The national response rates for the 2017, 2016 and 2015 surveys are $89.1 \%, 89.4 \%$, and $98.8 \%$ respectively (Stats SA., 2015; Stats SA., 2017a).

\section{Variables and Data Analysis Strategy}

This study combines descriptive and binary regression analysis. Three binary logistic models are estimated for three dependent variables reflecting the presence of hunger in adults, children and hunger in either adult or child. The dependent variables are created from two questions on subjective hunger: "In the past 12 months, did an adult in the household go hungry because there wasn't enough food and in the past 12 months, did any child in the household go hungry because there wasn't enough food?" (Stats SA., 2017 b, p. 121). We apply a strict definition to hunger; any affirmative response to the question on whether anyone in the household went without food is coded as 1 for the experience of hunger and 0 otherwise. Subsistence farming is measuring using a question on home production; "Has the household been involved in the production of any kind of food or agricultural products during the past twelve months? (e.g. livestock, crops, poultry, food gardening, forestry, fish, etc.)" (Stats SA., 2017b, p. 125).
We employ a set of demographic and socioeconomic household characteristics as controls. These include: the gender of head of household, age of head of household, number of employed household members, self-reported race of household head, household size, toilet facility type, source of cooking fuel, source and distance to drinking water, total household income, and the receipt of a government grant by any household member. The survey sample settings are used during data analysis, which is conducted with Stata version 12.

\section{RESULTS AND DISCUSSIONS}

The descriptive statistics for the surveys from 2015 to 2017 are presented in Table 1 . The role of homegrown food as a livelihood coping mechanism is highlighted by the percentage of households who are involved in agricultural activities (the rate is reported in Table 1). Over the period examined subsistence farming rate in urban areas was steady at $5.5 \%, 5.0 \%$ and $5.5 \%$ respectively for 2015,2016 and 2017 . The average urban household size for the three years is 3 and the mean age of household head is approximately 45 years for all years. Mean total household income at current prices were approximately ZAR9,421.7, ZAR9,483.1 and ZAR9,678.7 for 2015, 2016 and 2017 respectively. It must however be noted that incomes in the GHS are imputed and do not provide a complete reflection of mean national incomes for the period. Urban households are predominantly male-headed.

Disaggregating household participation in agricultural activities by gender shows that female headed households $(\mathrm{FHH})$ are more likely to be involved in agricultural activities than male headed households $(\mathrm{MHH})$ (see Table 2). The 2015 GHS shows that $6.2 \%$ of $\mathrm{FHH}$ participated in agricultural activities compared to $5.1 \%$ of $\mathrm{MHH}$. Generally, in 2016 there was a slight drop in agriculture activities, especially so for $\mathrm{FHH}$. The 2017 survey suggests a recovery from a 2016 dip with regard to the participation rate for $\mathrm{FHH}$.

In Table 3, we examine the rate of hunger in urban households from 2015 to 2017 . The data reveals little change in the rates of hunger for the period. In 2015 the total rate of adult's hunger was approximately $14.9 \%$; this remained unchanged in 2016 and dropped marginally in 2017 to 14.2 . Statistical tests suggest though that these levels remain unchanged as the changes are not statistically significant.

The incidence of hunger, when disaggregated by gender of the household head, shows that $\mathrm{FHH}$ 
Table 1: Summary Statistics for 2015,2016 and 2017 Surveys

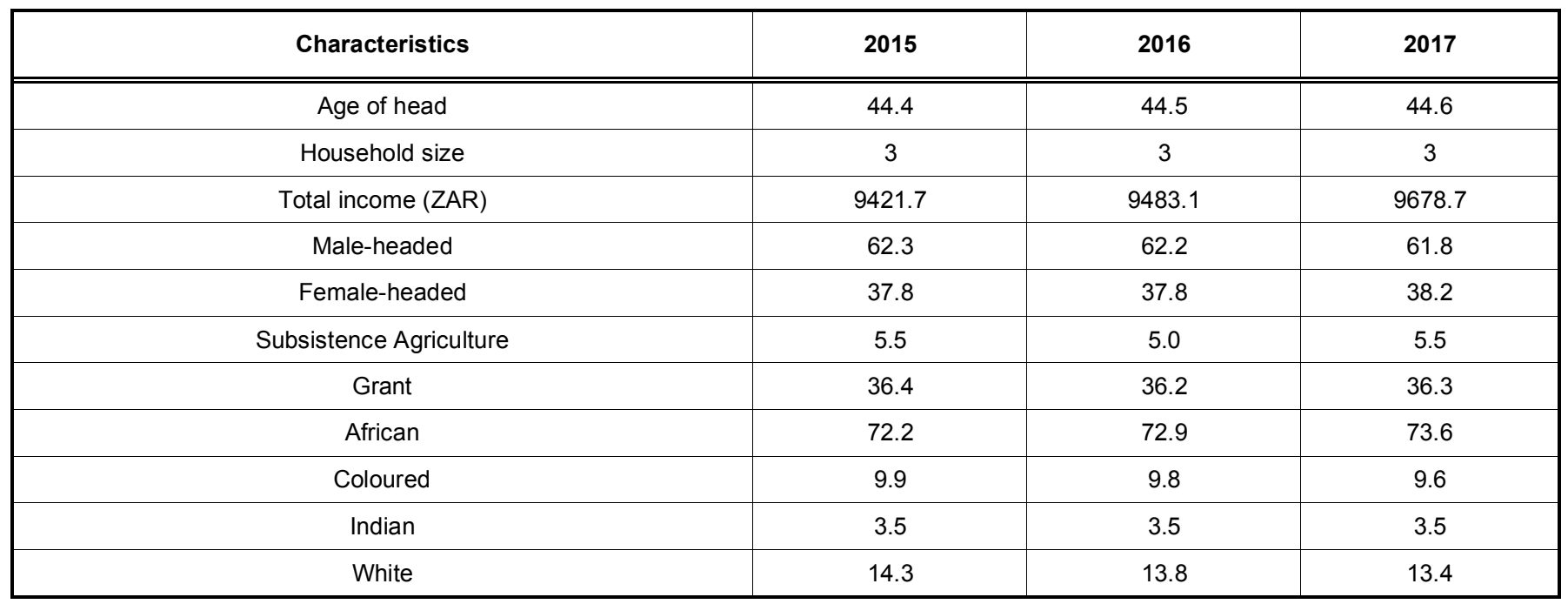

Computed by authors using data from the 2015, 2016 and 2017 GHS.

Table 2: Subsistence Agricultural Activities by Gender of Household Head (\%)

\begin{tabular}{|c|c|c|}
\hline Subsistence & $\mathbf{2 0 1 5}$ & $\mathbf{2 0 1 6}$ \\
\hline \hline Female-headed households & 6.2 & 5.0 \\
\hline Male-headed households & 5.1 & 5.0 \\
\hline
\end{tabular}

Computed by authors using data from the 2015, 2016 and 2017 GHS.

Table 3: Household Level Hunger Incidences in Urban Areas (\%)

\begin{tabular}{|c|c|c|c|c|c|c|c|c|c|}
\hline \multirow{2}{*}{ Hunger incidences } & \multicolumn{3}{|c|}{2015} & \multicolumn{3}{|c|}{2016} & \multicolumn{3}{|c|}{2017} \\
\hline & Male & Female & Total & Male & Female & Total & Male & Female & Total \\
\hline Hunger (Adult) & 13.3 & 17.4 & 14.9 & 13.3 & 17.9 & 15 & 12.1 & 17.6 & 14.2 \\
\hline Hunger (Child) & 12.7 & 20.1 & 15.9 & 12.8 & 20.6 & 16.2 & 12.2 & 20.7 & 15.9 \\
\hline Hunger (Both adult and child) & 15.3 & 23.4 & 18.9 & 14.9 & 23.4 & 18.7 & 14.6 & 23.5 & 18.5 \\
\hline
\end{tabular}

Computed by authors using data from the 2015, 2016 and 2017 GHS.

experience higher rates of hunger than $\mathrm{MHH}$. Table 3 also shows that on average $\mathrm{FHH}$ experience a higher rate of hunger in all categories of hunger examined for all years than $\mathrm{MHH}$. For hunger in adults, $\mathrm{FHH}$ recorded hunger levels of $17.4 \%, 17.9 \%$ and $17.6 \%$ respectively for 2015, 2016 and 2017 . This compares with adult hunger levels of; $13.3 \%, 13.3 \%$ and $12 . \% 1$ respectively for $\mathrm{MHH}$ also for 2015, 2016 and 2017. These higher levels of hunger in $\mathrm{FHH}$ were maintained when we examine hunger in children. $\mathrm{FHH}$ with children not only recorded higher levels of hunger than $\mathrm{MHH}$ with children but also the levels of child hunger were higher than adult hunger in $\mathrm{FHHs}$.

The logistic regression analysis confirmed the association between all three measures of hunger examined and the following variables: household size, education of the head of household, age of head, the race of head, refined cooking fuel, incomes and the number of employed household members (see Table 4). However, subsistence agriculture was not significant, and the gender of head of the household while not significant in the model for hunger in adult was significant in the child and the model for hunger in either child or adults.

Economic variables such as social grant, number of employed persons in household and total household income show a significant association in all three models of hunger examined. More so, with increasing incomes, households were less likely to be hungry. Additionally, households with more employed members 
Table 4: Logistic Regression Model with Dependent Variable Measuring Hunger in Children, Adults and both (Coded as $0=$ Absence of Hunger and $1=$ Presence of Hunger)

\begin{tabular}{|c|c|c|c|c|c|c|c|c|c|c|c|c|}
\hline \multicolumn{5}{|c|}{ Adult Hunger } & \multicolumn{4}{|c|}{ Child hunger } & \multicolumn{4}{|c|}{ Both (adult and child) } \\
\hline & \multirow{2}{*}{$\frac{\text { Odds Ratio }}{0.95}$} & \multirow{2}{*}{$\begin{array}{l}\text { Std. } \\
\text { Err. }\end{array}$} & \multicolumn{2}{|c|}{$\begin{array}{c}\text { [95\% Conf. } \\
\text { Interval] }\end{array}$} & \multirow{2}{*}{$\begin{array}{l}\text { Odds } \\
\text { Ratio } \\
0.86^{\star * *}\end{array}$} & \multirow{2}{*}{$\begin{array}{l}\text { Std. } \\
\text { Err. }\end{array}$} & \multicolumn{2}{|c|}{$\begin{array}{c}\text { [95\% Conf. } \\
\text { Interval] }\end{array}$} & \multirow{2}{*}{$\frac{\text { Odds Ratio }}{0.88^{\star *}}$} & \multirow{2}{*}{$\begin{array}{l}\text { Std. } \\
\text { Err. }\end{array}$} & \multicolumn{2}{|c|}{$\begin{array}{c}\text { [95\% Conf. } \\
\text { Interval] }\end{array}$} \\
\hline Male head & & & 0.89 & 1.02 & & & 0.79 & 0.94 & & & 0.81 & 0.96 \\
\hline $\begin{array}{l}\text { Household } \\
\text { size }\end{array}$ & $1.13^{* * *}$ & 0.01 & 1.11 & 1.15 & $1.08^{* \star *}$ & 0.01 & 1.06 & 1.10 & $1.09^{* * *}$ & 0.01 & 1.07 & 1.11 \\
\hline Head Age & $1.02^{* * *}$ & 0.01 & 1.01 & 1.04 & $1.03^{* *}$ & 0.01 & 1.01 & 1.04 & 1.01 & 0.01 & 1.00 & 1.03 \\
\hline Head Age2 & $1.00^{* * *}$ & 0.00 & 1.00 & 1.00 & $1.00^{\star * *}$ & 0.00 & 1.00 & 1.00 & $1.00^{* *}$ & 0.00 & 1.00 & 1.00 \\
\hline $\begin{array}{c}\text { Head } \\
\text { Education }\end{array}$ & $0.65^{\star * *}$ & 0.03 & 0.60 & 0.70 & $0.64^{\star * *}$ & 0.03 & 0.58 & 0.71 & $0.65^{* * *}$ & 0.03 & 0.59 & 0.71 \\
\hline \multicolumn{13}{|c|}{ Head Race ref: black } \\
\hline coloured & 0.88 & 0.04 & 0.80 & 0.97 & $0.79^{* * *}$ & 0.05 & 0.70 & 0.90 & $0.82^{* * *}$ & 0.05 & 0.73 & 0.92 \\
\hline indian & $0.18^{* * *}$ & 0.04 & 0.12 & 0.27 & $0.20^{\star \star *}$ & 0.06 & 0.11 & 0.37 & $0.22^{* * *}$ & 0.06 & 0.13 & 0.37 \\
\hline white & $0.27^{\star \star *}$ & 0.04 & 0.21 & 0.37 & $0.41^{\star \star \star}$ & 0.08 & 0.28 & 0.58 & $0.46^{\star \star *}$ & 0.07 & 0.33 & 0.63 \\
\hline $\begin{array}{l}\text { Subsistence } \\
\text { agriculture }\end{array}$ & 0.98 & 0.06 & 0.86 & 1.10 & 0.86 & 0.07 & 0.74 & 1.00 & 0.94 & 0.07 & 0.82 & 1.09 \\
\hline Social Grant & $1.43^{\star \star *}$ & 0.06 & 1.32 & 1.55 & $1.34^{\star \star *}$ & 0.08 & 1.20 & 1.51 & $1.38^{* * *}$ & 0.08 & 1.24 & 1.54 \\
\hline $\begin{array}{l}\text { Refined } \\
\text { cooking }\end{array}$ & $0.58^{* \star *}$ & 0.03 & 0.52 & 0.64 & $0.64^{\star \star \star}$ & 0.05 & 0.55 & 0.74 & $0.64^{* * *}$ & 0.05 & 0.56 & 0.74 \\
\hline Income & $0.69^{* * *}$ & 0.01 & 0.67 & 0.71 & $0.74^{\star \star *}$ & 0.01 & 0.71 & 0.77 & $0.72^{\star * *}$ & 0.01 & 0.70 & 0.75 \\
\hline Employed & $0.75^{\star \star \star}$ & 0.02 & 0.71 & 0.78 & $0.71^{* \star *}$ & 0.02 & 0.66 & 0.75 & $0.74^{\star * *}$ & 0.02 & 0.70 & 0.78 \\
\hline 2015 & 1.04 & 0.04 & 0.96 & 1.13 & 1.00 & 0.05 & 0.90 & 1.10 & 1.02 & 0.05 & 0.93 & 1.12 \\
\hline 2016 & 1.10 & 0.04 & 1.01 & 1.19 & 1.03 & 0.05 & 0.93 & 1.14 & 1.01 & 0.05 & 0.92 & 1.11 \\
\hline Constant & $5.46^{* * *}$ & 1.04 & 3.76 & 7.93 & $3.68^{\star * *}$ & 0.99 & 2.18 & 6.22 & $6.00^{* * *}$ & 1.56 & 3.61 & 9.97 \\
\hline
\end{tabular}

Computed by authors using data from the 2015,2016 and 2017 GHS ${ }^{* \star *} p<0.01,{ }^{* \star} p<0.05$, level.

are less likely to experience hunger. Increasing household size increases the likelihood of experiencing hunger.

The regression established that $\mathrm{FHH}$ are more likely to experience hunger than in $\mathrm{MHH}$. Also, homes using refined cooking fuel sources such as electricity and LPG gas were significantly less likely to experience hunger than homes that used other sources of fuel like dung, coal and firewood. Examination of the relationship between at least one member of a household receiving a government grant and hunger shows that urban families were less likely to be hungry if they had at least one member who received a social grant.

Engaging in some form of subsistence agriculture was not significantly associated with the experience of hunger in urban areas. Race of household head was significantly associated with hunger. Compared to the reference race group of black, all other households were less likely to experience hunger. The variable on the education level of household head was a dichotomous variable indicating higher than basic. This variable was negatively and significantly associated with hunger in all three models suggesting that households heads with higher than basic education are less likely to have members experiencing hunger than those with only primary school education.

The analysis further reveals there has been little change in the levels of hunger in urban areas from 2015 to 2017. Coupled with the steady increase in urban population share, these results point to an increase in the actual numbers of people experiencing hunger. Figure 1 illustrates this by examining a decade of urban population share, child and adult hunger respectively.

Additionally, the gender dimension of poverty is once again highlighted by the fact that female-headed households for all three categories of hunger examined experience higher levels than male-headed households. Poverty in South Africa continues to exhibit gender disparities with women-headed households more likely to be poor (Posel and Rogan, 2012) and hungry than those of males (Tibesigwa and Visser, 2015). This outcome has been shown by other 


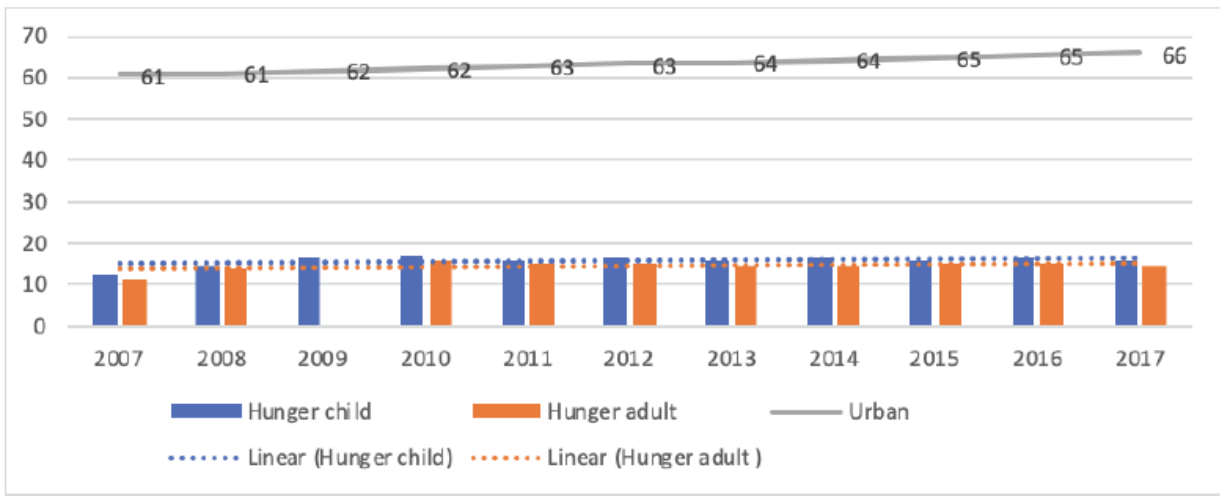

Figure 1: Trends in hunger and urban population share computed by authors using data from various GHS.

studies (Mallick and Rafi, 2010; Crush and Frayne, 2011) using other measures of deprivation, and it is critical to note that the pattern continues to dominate in an essential measure such as hunger.

Contrary to our expectation, subsistence agricultural activities in urban areas did not show significant association with hunger. Similar results (Crush, Hovorka and Tevera, 2011; Frayne, McCordic and Shilomboleni, 2014) have been found in studies while a few studies have illustrated the importance of subsistence agriculture in safeguarding food security. Evidence from the GHS shows that South African urban households have a rather low participation rate in agriculture activities compared with other developing countries (Rogerson, 1993).

Income is one of the key variables in reducing hunger and food insecurity (Aliber, 2003; Baiphethi and Jacobs, 2009; Hendriks, 2013). This was supported by the results of the study, which indicate that all three models suggests that social grants safeguard urban residents from hunger. This outcome resonates with several studies that find that social grants have positive impacts on various measures of food insecurity and nutrition (Case, 2001; Duflo, 2003; Ag et al., 2007; Coetzee, 2014). The results on grants and income variables in the analysis highlight that, for people from urban areas, receiving any form of money is essential for accessing food due to the heavy reliance of urban residents on food purchases (Baiphethi and Jacobs, 2009).

In South Africa, existing evidence (World Bank and Stats SA., 2018) shows that employment has increased in the post-1994 period, but the decline in poverty rates witnessed after 1994 is attributed to the expansion of the social safety nets. The evidence from the analysis conducted in this study indicates that having members of the household who are employed is essential for reducing hunger. Theoretically, an expansion of employment opportunities is expected to improve household income and consequently reduce both income poverty and food insecurity (Altman, Hart and Jacobs, 2009). In South Africa, employment has expanded but has failed to fully address poverty, however the presence of employment in a household is important in the reduction of income poverty and food insecurity Altman, Hart and Jacobs (2009).

\section{CONCLUSIONS AND RECOMMENDATIONS}

While the proportion of urban households experiencing hunger has not increased substantially, the steady growth of the urban population means that more South Africans will go without food in the long run. Our findings show that women and children bear the brunt of hunger, as households that report children going without food are consistently higher. Also, female-headed households record higher levels of hunger in both children and adults.

While much has been written on the role of homeproduced food in safeguarding food security (Bhaiphethi and Jacobs 2009; Tibesigwa, and Visser 2015; Chihambakwe, Mafongoya and Jiri 2018), evidence shows that in South Africa's urban areas efforts to reduce hunger should be focused on expanding economic opportunities. More so, urban households are more likely to rely on the purchase of food rather than home food production. However, evidence from other countries (Gallaher et al., 2013; Bellwood-Howard et al., 2015) indicates that the role of home-produced food in increasing access to food and thus reducing hunger should not be underestimated. Existing evidence, coupled with the reported low levels of urban farming in South Africa points to the need to pay attention to home food production of both crop and livestock. 
Even though our study was not designed to assess the effectiveness of social safety nets, our findings suggest that social safety nets play a crucial role in the fight against hunger. The association between receiving a government grant and hunger points to the potential role to be played by government grants in ensuring food security and the levels of children going without food suggest that these social safety nets are vital if we are to reduce the levels of child malnutrition. South Africa has the most comprehensive social safety net programme in Africa (World Bank and Stats SA., 2018) with seven unconditional cash transfers reaching approximately $44 \%$ of all households in the country (Ferguson, 2015). While our results suggest that these social safety nets safeguard urban residents especially children from hunger, evidence (Devereux and Waidler, 2017) points to the critical need to relook at the amounts of some of these grants.

\section{LIMITATIONS}

This study relied on readily available quantitative data to provide insights into the association between subsistence farming and hunger in urban areas and due to the nature of the data the study was only able to outline the correlates. We acknowledge this as a limitation, ultimately the question of how subsistence farming may be leveraged to mitigate hunger in the context of a rapidly urbanising Africa may only be addressed with more nuanced data. We therefore propose this as an area for further research.

\section{REFERENCES}

AfDB., UNDP. and OECD (2016) Sustainable Cities and Structural Transformation. Abidjan, Paris and New York. Available at: https://www.afdb.org/fileadmin/uploads/afdb/Documents/Publ ications/AEO_2016_Report_Full_English.pdf.

Ag, J. M. et al. (2007) The Impact of Unconditional Cash Transfers on Nutrition: The South African Child Support Grant, Food Policy. doi: Retrieved from http://opensaldru.uct.ac.za/ handle/11090/46.

Aliber, M. (2003) 'Chronic poverty in South Africa: Incidence, causes and policies', World Development, 31(3), pp. 473-490. https://doi.org/10.1016/S0305-750X(02)00219-X

Altman, M., Hart, T. and Jacobs, P. (2009) 'Household food security status in South Africa', Agrekon. Available at: http://www.tandfonline.com/doi/abs/10.1080/03031853.2009. 9523831 (Accessed: 24 October 2014).

Arndt, C., Davies, R. and Thurlow, J. (2019) Urbanization, structural transformation, and rural- urban linkages in South Africa. 41. Pretoria.

Baiphethi, M. and Jacobs, P. (2009) 'The contribution of subsistence farming to food security in South Africa', Agrekon. https://doi.org/10.1080/03031853.2009.9523836

Battersby, J. (2011) 'Urban food insecurity in Cape Town, South Africa: An alternative approach to food access', Development Southern Africa, 28(4), pp. 545-561. https://doi.org/10.1080/0376835X.2011.605572
Battersby, J. (2012) 'Beyond the food desert: Finding ways to speak about urban food security in South Africa', Geografiska Annaler, Series B: Human Geography. https://doi.org/10.1111/j.1468-0467.2012.00401.x

Bellwood-Howard, I. et al. (2015) Urban and Peri-urban Agriculture in Tamale: A Policy Narrative. Available at: http://www. urbanfoodplus.org/fileadmin/user_upload/Pictures/Publicatio ns/Policy_narrative_UPA_in_Tamale_2015_11.pdf.

Bhorat, H. and Naido, K. (2017) '03 - (UNDP Report 2017) - Chapter 3 - Drivers of Inequality in the Context of the Growth-PovertyInequality Nexus in Africa: An overview of key issues', in Income Inequality Trends in sub-Saharan Africa: Divergence, Determinants and Consequences, pp. 52-73. Available at: http://www.africa.undp.org/content/rba/en/home/library/report s/income-inequality-trends-in-sub-saharan-africa-divergencedete.html\%0Awww.africa.undp.org/content/dam/rba/docs/Re ports/undp-rba_Income Inequality in SSA_Chapter 3.pdf?download.

Bryld, E. (2003) 'Potentials, problems, and policy implications for urban agriculture in developing countries', Agriculture and Human Values. https://doi.org/10.1023/A:1022464607153

Case, A. (2001) 'Does Money Protect Health Status? Evidence from South African Pensions', NBER Working Paper 8495: Cambridge, MA., (October), pp. 1-32. https://doi.org/10.2139/ssrn.279919

Chihambakwe, M., Mafongoya, P. and Jiri, O. (2018) 'Urban and Peri-Urban Agriculture as A Pathway to Food Security: A Review Mapping the Use of Food Sovereignty', Challenges. https://doi.org/10.3390/challe10010006

Coetzee, M. (2014) 'Do poor children really benefit from the child support grant'. Available at: http://www.econ3×3.org/sites/ default/files/articles/Coetzee 2014 Child grant FINAL.pdf (Accessed: 28 January 2019).

Crush, J., Hovorka, A. and Tevera, D. (2011) 'Food security in Southern African cities: The place of urban agriculture', Progress in Development Studies. https://doi.org/10.1177/146499341001100402

Crush, J. S. and Frayne, G. B. (2011) 'Urban food insecurity and the new international food security agenda', Development Southern Africa. https://doi.org/10.1080/0376835X.2011.605571

Devereux, S. and Waidler, J. (2017) Why does malnutrition persist in South Africa despite social grants? 1. Cape Town and Pretoria. Available at: https://foodsecurity.ac.za/wpcontent/uploads/2018/04/Final_Devereux-Waidler-2017Social-grants-and-food-security-in-SA-25-Jan-17.pdf.

Duflo, E. (2003) 'Grandmothers and Granddaughters: Old-Age Pensions and Intrahousehold Allocation in South Africa', The World Bank Economic Review, 17(>1), pp. 1-25. https://doi.org/10.1093/wber/lhg013

Egal, F., Valstar, A. and Meershoek, S. (2001) 'Urban Agriculture, Household Food Security and Nutrition in Southern Africa', in Baudoin, W., FAO, and Vink, N. (eds) Sub-Regional Expert Consultation on the Use of Low Cost and Simple Technologies for Crop Diversification by Small-Scale Farmers in Urban and Peri-Urban Areas of Southern Africa Stellenbosch, South Africa. Stellenbosch. Available at: http://www.fao.org/fileadmin/templates/FCIT/PDF/urban_food _security_ssa.pdf.

FAO. (2010) The State of Food Insecurity in the World Addressing food insecurity in protracted crises FOOD AND AGRICULTURE ORGANIZATION OF THE UNITED NATIONS Rome, 2010. Rome.

FAO et al. (2018) The State of Food Security and Nutrition in the World 2018. Building climate resilience for food security and nutrition. Rome. Available at: http://www.fao.org/3/i9553en/ i9553en.pdf. 
Faye, O. et al. (2011) 'Hunger and food insecurity in Nairobi's slums: An assessment using IRT models', Journal of Urban Health. https://doi.org/10.1007/s11524-010-9521-x

Ferguson, J. (2015) Give a Man a Fish: Reflections on the New Politics of Distribution*. Durham: Duke University Press. https://doi.org/10.3917/socio.084.0457

Frayne, B. (2005) 'Survival of the poorest: migration and food security in Namibia', AGROPOLIS: the social, political, and environmental ... Available at: http://books.google.co.za/books?hl=en\&lr=\&id=0_KOK1_yhl8 C\&oi=fnd\&pg=PA31\&dq=migration+and+food+security+\&ots =BZCiCRohPD\&sig=OoDsoTuPXL-1-gR3lf7ndo4DOhl (Accessed: 24 October 2014).

Frayne, B., McCordic, C. and Shilomboleni, H. (2014) 'Growing Out of Poverty: Does Urban Agriculture Contribute to Household Food Security in Southern African Cities?', Urban Forum. https://doi.org/10.1007/s12132-014-9219-3

Gallaher, C. M. et al. (2013) 'Urban agriculture, social capital, and food security in the Kibera slums of Nairobi, Kenya', Agriculture and Human Values. https://doi.org/10.1007/s10460-013-9425-y

Gardner, D. (2018) 'South African Urbanisation Review. Analysis of the Human Settlement Programme and Subsidy Instruments', in. Pretoria. Available at: https://csp.treasury. gov.za/Resource__Centre/Conferences/Documents/ Urbanization Review Papers/Paper 6 - Analysis of HS Programme.pdf.

Hendriks, S. (2013) FOOD SECURITY IN SOUTH AFRICA: STATUS QUO AND POLICY IMPERATIVES AEASA Presidential Address 1 October 2013, Bela Bela Sheryl Hendriks 1. Available at: https://repository.up.ac.za/bitstream/handle/ 2263/40789/Hendriks Food 2014.pdf?sequence=1 (Accessed: 14 December 2018).

IFPRI (2017) 2017 Global food policy report. Washington DC. Available at: http://www.ifpri.org/publication/2017-globalfood-policy-report.

Mallick, D. and Rafi, M. (2010) 'Are Female-Headed Households More Food Insecure? Evidence from Bangladesh', World Development. https://doi.org/10.1016/j.worlddev.2009.11.004

National Department of Human Settlements. (2015) Housing White Paper: Towards a policy foundation for the development of human settlements legislation. Pretoria. Available at: http://pmg-assets.s3-website-eu-west-1.amazonaws.com/ DHS_FINAL_REVISED_STRATEGIC_PLAN_2015_2020.pdf

Ncube, D. and Ncube, N. (2016) 'Urban Agriculture and Food Security: A Case Study of Old Pumula Suburb of Bulawayo in Zimbabwe', Global Journal of Advanced Research, 3(8), pp. 771-782. Available at: http://gjar.org/publishpaper/ vol3issue8/d556r92.pdf.

NRC (2006) Food Insecurity and Hunger in the United States: An Assessment of the Measure. Washington, D.C. Available at: https://www.nap.edu/catalog/11578/food-insecurity-andhunger-in-the-united-states-an-assessment.

Parliamentary Monitoring Group (2018) Urbanisation. Available at: https://pmg.org.za/page/Urbanisation.

Posel, D. and Rogan, M. (2012) 'Gendered trends in poverty in the post-apartheid period, 1997-2006', Development Southern Africa. https://doi.org/10.1080/0376835X.2012.645645
Ravallion, M., Chen, S. and Sangraula, P. (2007) 'New evidence on the urbanization of global poverty', Population and Development Review. https://doi.org/10.1111/j.1728-4457.2007.00193.x

Rogerson, C. M. (1993) 'Urban agriculture in South Africa: Scope, issues and potential', GeoJournal. doi: 10.1007/BF00807823.

Ruel, M. T. and Garrett, J. L. (2004) 'Features of Urban Food and Nutrition Security and Considerations for Successful Urban Programming', eJADE: Electronic Journal of Agricultural and Development Economics.

SACN (2016) State of South African Cities Report 2016 Johannesburg. Available at: http://www.sacities.net/wpcontent/uploads/2016/SOCR/SoCR16 Main Report online.pdf.

Seto, K. C. et al. (2017) 'Urbanization in Africa: challenges and opportunities for conservation', Environmental Research Letters, 13(1). https://doi.org/10.1088/1748-9326/aa94fe

Stats SA. (2015) General household survey 2015. Pretoria. Available at: http://www.statssa.gov.za/publications/P0318/P03182015. pdf

Stats SA. (2017a) General Household Survey, 2016. Pretoria.

Stats SA. (2017b) General Household Survey 2017. Pretoria.

Szabo, S. (2016) 'Urbanisation and Food Insecurity Risks: Assessing the Role of Human Development', Oxford Development Studies. https://doi.org/10.1080/13600818.2015.1067292

Thornton, A. C. and Nel, E. (2007) 'The significance of urban and peri-urban agriculture in Peddie, in the Eastern Cape province, South Africa', Journal of Development Studies, 37(1), pp. 13-20. Available at: https://journals.co.za/ content/canus/37/1/EJC22632.

Tibesigwa, B. and Visser, M. (2015) Small-scale Subsistence Farming, Food Security, Climate Change and Adaptation in South Africa: Male-Female Headed Households and UrbanRural Nexus. 527. Pretoria.

UN-HABITAT. (2016) Urbanisation and Development: Emerging Futures. Nairobi. Available at: United Nations Human Settlement Programme (UN HABITAT) 2016 The Economic role of cities 2016.

UN (2018) 'The speed of urbanization around the world', Population Facts.

UN DESA (2018) $68 \%$ of the world population projected to live in urban areas by 2050, says UN, Webpage News.

UNICEF (2010) Understanding Urban Inequalities in Bangladesh: A prerequisite for achieving Vision 2021. Dhaka. Available at: https://www.unicef.org/socialpolicy/files/Urban paper_lowres. pdf.

van Veenhuizen, R. (ed.) (2006) Cities Farming for the Future: Urban Agriculture for Green and Productive Cities. IIRR, RUAF IDRC. Available at: https://www.idrc.ca/en/book/citiesfarming-future-urban-agriculture-green-and-productive-cities.

World Bank and Stats SA (2018) 'Overcoming Poverty and Inequality in South Africa: An Assessment of Drivers, Constraints and Opportunities', World Bank.

Wurwarg, J. (2014) 'Urbanization and hunger: Food policies and programs, responding to urbanization, and benefitting the urban poor in three cities', Journal of International Affairs

\section{DOl: https://doi.org/10.6000/1929-7092.2020.09.18}

(c) 2020 Jonah et al.; Licensee Lifescience Global.

This is an open access article licensed under the terms of the Creative Commons Attribution Non-Commercial License (http://creativecommons.org/licenses/by-nc/3.0/) which permits unrestricted, non-commercial use, distribution and reproduction in any medium, provided the work is properly cited. 